\title{
塗膜によるシエア・パルスの減衰篦 $\begin{aligned} & \text { UDC } \\ & ; 5374-8\end{aligned}$ \\ Attenuated Reflection of Shear Pulses by Films
}

\author{
Raymond R. Myers* \\ （訳 元山芳彰**・井上忠良档・吉田豊颜料，
}

\section{訳者ま觉がき}

Raymond R. Myers 教授は 1968 年 10 月, 国際レオ ロジー会議で研究発表をするために訪日された。来日に 際し，塗料物性研究会のことを知って関心を示されたの で会として扣話を伺ら機会を得たいと考えたが，教授の 日程の都合で, 10 月 18 日色材協会の研究発表・特別請 演会で特別講演を和願いすることになつた。これはこの 講演の草稿であるが，当日の講演はこの草稿だけによら ず, 自由に進められたので, 必ずしもこの草稿の通りで はない。当日の講演を本誌に記載することについて教授 の快諾が与えられたが，録音をとっておかなかつたので， 草稿を訳出した次第である。

\section{序}

塗料工業では試験法を用いて実用的な答を得ようとす る。たとえば乾燥時間記録計は塗膜がいつ乾燥するかと いらことだけを測定するよらに設計されている。塗膜の 構造と性質を関係づけようとする基本的な目的に预いて はほとんど進歩がない。これは一つには乾燥工程の研究 が特定の塗装系に重きを置いてなされ，また一つには管 理さ饥た科学的な測定法が塗膜に対してはめつたに用い られなかったからである。

すべての乾燥過程には一つだけ共通点がある。すなわ ち, 液状の皮膜または, 塑性物質が表面に塗装された後 に高度の剛性率に達することである。剛性を高くする方 法にはいろいろあるが，ここでは塗料工業において最も 良く使われている方法を選んで塗料が塗装されてから乾 燥するまでの過程の粘弾性变化を完全に測定する新しい 試みを報告する。

昭 44.3 .11 受理

* Kent State University, Kent, Ohio, U.S.A.

** 日本油脂株式会社戸塚工場 横浜市戸塚区下倉田町

\section{乾 燥 過 程}

乾㖥は塗膜に一つの根本的な物理変化を与える。表一 に一般に認的られた液体から固体への乾燥機構が複雑さ の順に並べてある。上の方は物理的な機構で, 下へくる ほど化学的なものになつている。もちろんいかなる乾燥 機構にも, 乾燥中にめるいは乾燥後に化学変化が起こる。

表-1 乾 燥 機 構

\begin{tabular}{|c|c|}
\hline 機 & 例 \\
\hline 冷 却（凍結） & シーリングワックス \\
\hline 溶剤の蒸 発 & ラッカー \\
\hline 素地への浸透 & 紙コーチング \\
\hline 分散相のコアレッセンス & ラテックスペイント \\
\hline ゲ ル 化 & アルミニウムアルコレート \\
\hline 水 素 結 合 & デンプン \\
\hline $\mathrm{C}-\mathrm{C}$ 縮合 & 重 合 \\
\hline 酸 化 重 合 & アマニ油，アルキド \\
\hline
\end{tabular}

特殊な場合を除けばすべての乾燥機構では, 乾燥塗膜 の性質や付着性は素地の影響を受けるが, 塗膜が乾燥す るか否かは素地には無関係である。それゆえ, われわれ の研究では素地として力学的性質の十分にわかつてい る，また，再生可能な溶融石英を用いた。

\section{塗膜 乾燥理 論}

塗液の性質はその粘度 クとそのズリ依存性によってか. なり正確に表わすことがでさる。もちろん，これらの性 質は塗液の塗膜形成能についてだけ情報を与えるもの で，乾燥状態についてはなにも情報を与えない。

同様に乾燥塗膜の性質は弾性率 $G$ で表わされる。

与えられた組成を有する物質の力学的性質は, 特にそ. の物質が液体と固体の両者の性質を示す時には, 粘度 $\eta$ と弾性率 $G$ に依存する。与えられた応力条件の下で, あ る物質が液体としてか, または固体として作用するかは. 
$\eta$ そGとの相対值，または絶対值によって決定され，同 様に塗膜がもろいか, もろくないか, 硬いか軟らかいか, 塑性が有るか無いかもクとGで決まる。

塗膜の乾燥中に起こるレオロジカルな変化は，まず粘 度が著しく上昇し，それに続いてまたは同時に剛性率が 上昇する。乾燥過程が進さにしたがって塗膜の弾性率 $G$ が粘ちゅら度の重要な決定要素になってくる。これはも らろん，クが増加するにつれて塗膜が与えられたエネル ギーを熱として消費しないで，貯觉るよらになるからで ある。

\section{塗膜乾燥の動的評価}

弾性率 $G$ 直接求めるには応力を塗膜の伸びの関数と して測定し, 粘度クを直接求めるには応力を伸び速度の 関数として測定する。特に試験片が成型できないような 粘弾性物質に対しては, 力学的特性値 $\eta^{\prime}$ と $G^{\prime}$ は一般に 繰返しセン断応力を用いて測定される。光と $\eta^{\prime}$ はとれ ぞれ動的粘性率，動的剛性率と呼ばれる。

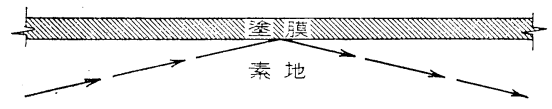

図-1 塗膜一素地界面からのズリ波の反射 膜のコンシステンシーはインピーダンスとして 表わされる。インピーダンスは，反射したズリ 波の強度を支配する。

薄い塗膜に最適な測定方法は図-1 に示すように素地 を通って塗膜に衝突する超音セン断波に塗膜ぶ与える機 械的なインピーダンス $Z$ を測定する方法である。進行方 向と直角に, 界面に平行な方向に指向された音波が素地 中を伝ぱして界面で反射した後, 振巾測定機の感知端に 到着する。 $Z$ は系の幾何学的形状と素地のインピーダン スから計算される。石英が使われるのは $Z$ 值が正確に知 られているからでめる。塗膜が乾燥するにつれて超音波 エネルギーの吸収率が高くなり，反射波は減衰する。こ の方法は抵抗と蓄電器回路の（電気的）インピーダンス を測定するのに使われる方法と似ている。すなわち機械 的インピーダンスは抵抗の項と 90 度位相のずれた反発 項から成っている。

ここで述べられているインピドメーター (impedometer）の操作法では $\eta^{\prime}$ と $G^{\prime}$ を分離して計算することは できない。この装置は Mason, Baker, McSkimin, Heiss $^{1)}$ らによって蛞めて提晿され，後に Barlow や $\mathrm{Lamb}^{2}$ らによって潤滑油の研究に用いられた。この装 置には Pellam, Galt3) の開発したパルスエコー技術が 取り入れられている。5〜15 mhz の $4 \mu \mathrm{sec}$ のパルスが

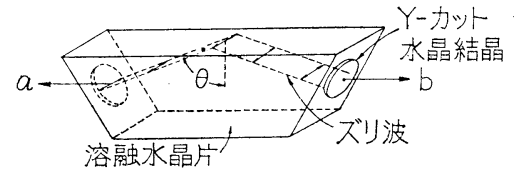

図-2 超音波インピドィーター 塗膜は溶融水晶片の表面に塗る，aから bへの反射 波の強度の減衰は, インピーダンスとして測定され る。ズリ波は進行方向に直角に偏光されたもので, 入射角は法線からかなり離れた角度である。 (Heuter and Bolt “Sonics" John Willey \& Sons, New York, から)

テーパーをつけた溶融石英の棒の先に接合された $\mathrm{Y}$ 字形 をした石英結晶に与えられる4)。この結晶は正確に配向 され，これから発するズリ波は水平方向に指向され，溶 融石英棒のテーパー部は波動を光学的に平らな側面へ導 くように設計されている(図-2)。この装置の電気系統 はPellan, Galt らが使用したものと汇とんど変りない。 連続的なパルスエコーがオシロスコープ上に描かれ る。シェアパルスの一部が塗膜への伝達部によって損失 となると, エコーの減衰となって表われる。全ての塗膜 形成系に拈いて, 損失の一部は弾性エネルギーとして塗 膜に貯えられ，また一部はエネルギーとして直ちに消費 される。

発振器 (図-3 のP) が $4 \mu \mathrm{sec}$ のパルス（図-4 参照) を発振し，これがシェアパルスに変換されてインピドメ 一ター中を伝ぱし，反射パルスはエコーと共にオシロス コープに写し出される。塗膜に供給された反射超音波エ ネルギーは 1/1000 秒以内に完全に減衰し, 1/100 秒後 に次のパルスが供給されてプロセスが繰り返される。

使用サイクルは $4 \times 10^{-4}$ であるからエネルギーの供給

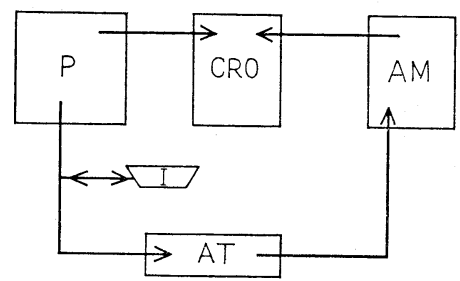

図-3 超音波パルスエコーインピドメーター のブロックダイヤグラム

電気的なパルスの進行方向を示した。水晶のパー (1)をシェア・パルスとして横断する。1からの 反射は $\mathrm{AM}$ で増幅され，CRO スクリーンに指数 的に減衰するピークの列として写し出される。ア テニュエーターATはスィッチ列からなっていて, デシベルで調整してある。要するに指数の対数を 抽出する役目をする。エコーの強度は線形に減衰 するようになる。 


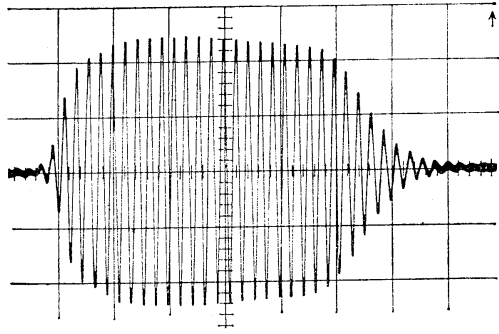

図-4 パル ス

増幅器の中の検出装置によって対称的なパルスを スパイクに変えてオシログラフに写す。これらの パルスの間隔はパルス幅よりもずっと大きい。

時間は測定時間の $0.04 \%$ に過ぎず，したがってこの測 定方法は非破壊的で岗るといえる。各反射によるエネル ギー損失の読みは減衰 $\Delta$ のデシベル $(\mathrm{dB})$ で表わす。

インピドメーターの表面になにも塗布されていない場 合にはセン断波の反射係数は最大值を取り，1であると 考兄られる。付着性物質がインピドメーターに塗布され 固化が進むとセン断波の一部分は塗膜中に浸透し, 塗布 されていない場合よりも反射信号は早く減衰する。

隣接する反射波のピークの高さの違いをデシベルで測 定することにより，塗膜の機械的インピーダンスを硬化 にしたがって追跡することができる。塗膜の下面でセン 断波の反射が行なわれていることに注意しょう。実際に はなにも塗布されていない場合でも, ある程度の減衰は 存在するので，全ての読みを補正する必要がある。

機械的インピーダンス $Z$ の变化を時間の関数として観 察することにより，いろいろな乾燥機構に存在する共通 点について知見を得ることができる。

交流理論と同様に $Z$ は二つの成分から成り立ってい る。すなわち，レジスタンス $R$ とリアクタンス $X$ であ る。伸びとズリ速度は互いに 90 度位相がずれているの で, 複素数の問題となる。数学的には $R, X$ に対する $Z$ の関係は式（1）のようになる。

$$
Z=R+i X
$$

ここで $i=\sqrt{-1}$

$$
Z=Z_{q} \cos \theta\left(\frac{1-r^{2}+2 i r \sin \phi}{1+r^{2}+2 r \cos \phi}\right)
$$

であるから、インピーダンスの実数部, 虚数部は式 (3) 式，(4) のようになる。

$$
\begin{aligned}
& R=\left(\frac{1-r^{2}}{1+r^{2}+2 r \cos \phi}\right) \\
& X=\left(\frac{2 r \sin \phi}{1+r^{2}+2 r \cos \phi}\right)
\end{aligned}
$$

ここで反射率 $r$ は $r=\log \left(\frac{-\Delta}{40}\right)$ の関係から求められ,
$Z_{q}$ は石英素地のインピーダンス， $\theta$ は入射角である。 $G^{\prime}, \eta^{\prime}$ は $R$ とから式 (5), 式 (6) によって求めら れる。

$$
\begin{aligned}
G^{\prime} & =\frac{R^{2}-X^{2}}{\rho} \\
\eta^{\prime} & =\frac{2 R X}{\rho \omega}
\end{aligned}
$$

ここでのは塗膜の密度, $\omega$ は circular frequency $(=2$ $\pi f)$ である。肩付きのプライムはデータが動的に得られ たことを示している。

\section{ラテックスの乾燥に関する動力学的研究}

この研究ではアクリルラテックスを用いた。全ての条 件は一定にした。最も重要な条件は相対湿度である。種 々の厚さの塗膜に対して図-5に示すよらな乾燥曲線が 得られた。乾燥速度はこれらの曲線のこら配関係して いるが，こう配が連続的に変化するには時間目盛を適当 に選ぶ必要がある。 $\log \Delta$ を時間に対してプロットする と図-6 のように各乾燥曲線の指数部が直線化されるの でこの問題を解決することができる。このこう配から乾 燥過程の最初の段階の比速度定数が得られる。

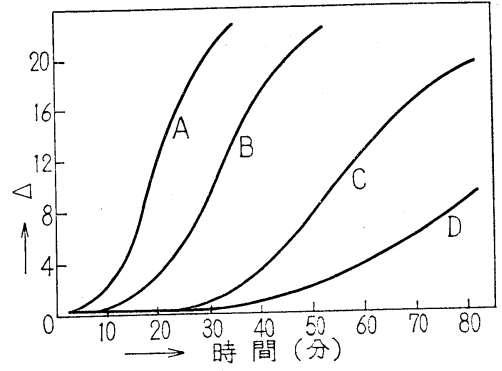

図-5 アクリルテテックスの乾燥曲線 粒子間の水が蒸発してしまうまで減衰は起こら ない。ラテックス粒子とインピドメーターの表 面の接触が多くなると 完全に接触すると曲線は平になる。膜厚 $(\mathrm{A} \rightarrow \mathrm{D}$ 大）が乾燥速度を支配する。

硬化過程は二つの段階に分けることができる。一つは 減衰率が一定である誘導期と, 他の一つは減衰率が滑ら かに増加して最終的には一般に $20 \Delta$ 以上の一定値に収 れんする乾燥期の二つである。

誘導期の終りは図-6 の切片から求められる。誘導期 間では塗膜は分散状態から間隙部に未だに水を含んだま まの, 最密充テン球状粒子へと移行し, 素地とは点接触 をしている。それから間隙に存在する水の蒸発が始ま り，ポリー粒子の変形が始まる。そこで粒子は素地に 対して平たん化され，最終的には連続膜を形成する。そ 


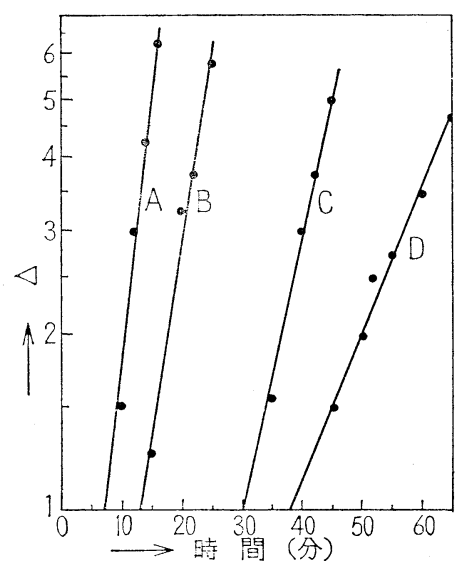

図-6 アクリルラテックスの線型乾燥曲線 誘導期の長さほ膜厚で変る, 誘導期が終ると減 衰は膜厚に応じて增加する。誘導期の推定には $\Delta_{0}=1$ なる点を用いた。

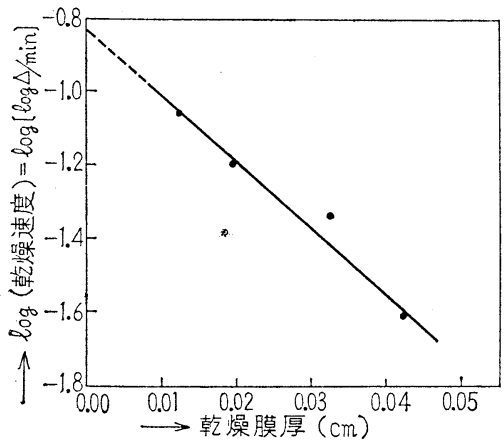

図-7 アクリルラテックスの乾燥速度の膜厚依存性 縦軸は図-6 の傾斜の対数, この図の直線の傾きは, $-17.8 \log (\log \Delta / \mathrm{min}) / \mathrm{cm}$

の後起こるであろう重合による乾燥段階が固化期間と呼 ばれる。球状粒子の点接触が多面体の面接触へ移行する とさだけに顕著な減衰が始まる。

乾燥速度は図-6 の直線のこ5配から直接求められる が，これらの速度は乾燥塗膜の厚さが増加するにつれて 指数的に減少する。そこで乾燥速度の対数を膜厚に対し てプロットしたのが図-7である。明らかに, 素地に接し ている粒子間吵からの水の損失は単なる蒸発ではなく, 拡散と繁発が連続して合わさったもので, 単純な数式で は表わされない。

\section{臨界温度域におけるアクリルラテックスの製膜}

ラテックスから作られた塗膜表面の性質は分散相であ るポリマーによって決まる。塗膜形成のための最低温度 (minimum film-forming temperature=MFT) はポリ
表-2 ポリマーの組成と性質

\begin{tabular}{c|c|c|c}
\hline $\begin{array}{c}\text { ラテックス } \\
\text { 番 号 }\end{array}$ & $\begin{array}{c}\text { 組 成 } \\
\mathrm{EA} / \mathrm{MMA}\end{array}$ & $\mathrm{MFT}\left({ }^{\circ} \mathrm{C}\right)$ & 固形分 $(\%)$ \\
\hline 1 & $35 / 65$ & 54 & 47.3 \\
2 & $40 / 60$ & 47 & 47.3 \\
3 & $45 / 55$ & 37 & 46.8 \\
4 & $50 / 50$ & 32 & 47.0 \\
\hline
\end{tabular}

マー粒子の粘弾性によって決まり，MFTを決定する主 因子は弾性率 $G$ で, 次に粘度 $\eta$ が影響する。

表-2 は，アクリル酸エチル $(\mathrm{EA})$ とメタクリル酸メチ ル(MMA)の共重合ラテックスの, EA/MMA 比と MFT の関係である。これらのラテックスは Rohm and Haas 社で合成したものである。

MFT, またはそれ以上の温度では図-5 のように密着 塗膜の特徵である $\mathrm{S}$ 字曲線が得られた。しかし MFT 以 下では減衰は最高値に達した後, 塗膜と素地表面との接 触面積によって決まる一定值まで減少した。これらの結 果から温度と乾燥速度が硬化塗膜の性質にどのように影 響するかを検討した。

これら 4 種のラテックスから図-8 に示すよらな乾燥 曲線が得られた。ここで得られたデータはすべて, 温度 $35^{\circ} \mathrm{C}$, 相対温度 $55 \%$ の条件においてで女る。No. 4 の ラテックスだけが MFT 以上であったので硬化し，連続 膜を作った。乾燥によるキ裂の発生や付着不良は MFT が高くなるにつれて増加した。

さらに MFTより $2^{\circ} \mathrm{C}$ 低い温度での乾燥速度の減衰を 湿度を $80 \%$ まで上げて研究した。No. 3 のラテックス をこの研究に用いた。表-3から $35^{\circ} \mathrm{C}$ に打いて臨界乾燥 速度というものが存在し，それ以下では減衰がないこと がわかる。この臨界乾燥速度5) わすと $0.079 〜 0.155$ の間にある。

図-9 から乾燥速度は塗膜性能の重要因子でめること がわかる。 $\log \Delta$ を時間に対してプロットすると図-6 と 同様に乾燥速度の算出 ${ }^{5)}$ ができる直線部分が乾燥過程の

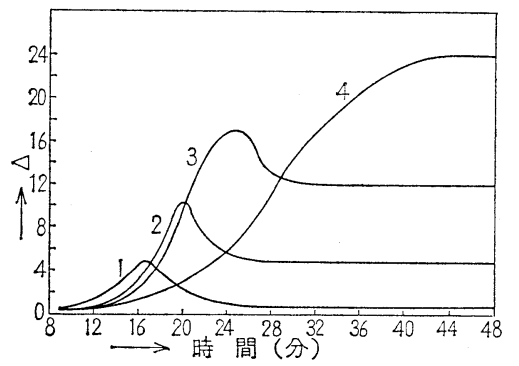

図-8 アクリルラテックス(表-2)の乾燥曲線 硬化は $35^{\circ} \mathrm{C} 55 \%$ 湿度でゆっくり行なった。 
表-3 アテニュエーションパターンに対する乾燥速 度の影響

\begin{tabular}{|c|c|c|c|c|c|}
\hline \multirow{2}{*}{$\begin{array}{l}\text { Key } \\
(\text { 図-3) }\end{array}$} & \multirow{2}{*}{$\begin{array}{c}\text { 相対湿度 } \\
(\%)\end{array}$} & \multirow{2}{*}{$\begin{array}{l}\text { 速 度 } \\
(\Delta / \mathrm{min})\end{array}$} & \multicolumn{3}{|c|}{$\begin{array}{c}\text { エコーごとの } \\
\text { アテニュエーション }\end{array}$} \\
\hline & & & ビーク & 乾燥塗膜 & 減衰 $(\%)$ \\
\hline A & 15 & 0.286 & 12.5 & 9.5 & 24 \\
\hline B & 35 & 0.238 & 15.5 & 10.0 & 23 \\
\hline $\mathrm{C}$ & 55 & 0.155 & 17.0 & 12.0 & 29 \\
\hline $\mathrm{D}$ & 80 & 0.079 & 18.8 & 18.0 & 0 \\
\hline
\end{tabular}

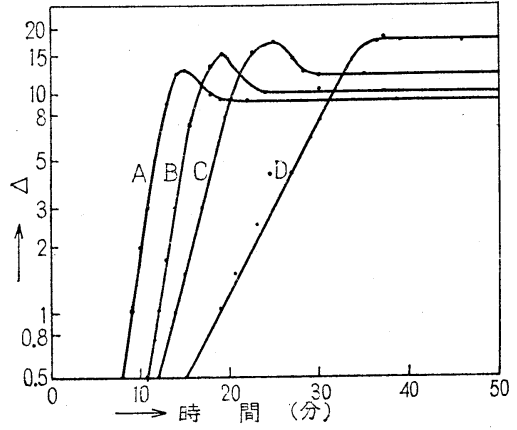

図-9 ラテックスの線型乾燥曲線 乾燥速度は曲線の傾きで求めた（条件は表-3に記した） どの瞬間にも存在することがわかる。

乾燥塗膜を顕微鏡写真でみるとひどいチェッキングを 起こした場合には接触面積は超音波によって得られたと

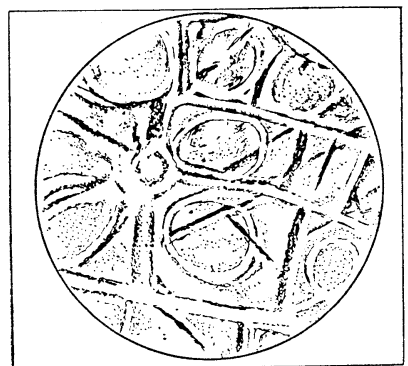

図-10 ラテックス 2 を $20^{\circ} \mathrm{C}(\mathrm{MF}$

T以下) で乾かしたものの位

相差顕微鏡写真 $\times 100$

円はチップの接触面積を示す
同じように全面積の 一部分であるにすぎ ないことがわかる。

図-10 は倍率 100 倍 の位相差顕微鏡写真 で，素地との接触は ポリマーの個々のチ ップの中心付近にあ る環を介してだけな されていることがわ かる。図-10をよく

見るとチップのある ものはまったく接触していないことがよくわかる。この ラテックスは $\mathrm{MFT} よ り 10^{\circ} \mathrm{C}$ 低い温度で乾燥した。

\section{ラテックスの凝集（Coalescence）}

1956 年 Brown はラテックスの塗膜形成に関する論 文6)を発表した。その中で，彼は塗膜の形成過程におい て隣り合った粒子が互いに融合して，粘性流動によって 膜を形成し，ポリマーの表面張力がセン断応力を生ずる という既存の仮説をくつがえした。温度が塗膜の性能に
影響することから, Brown はサスペンションの球の弾性 率の方が粘度より重要なパラメーターであるという仮説 を立てた。凝集過程に打いては水ーポリマー界面が最小 となるので自由エネルギーが減少する。

乾燥による塗膜の体積変化は素地と垂直方向に起こ る。このような条件下では塗膜はヒズミを受けるため, 側面からの応力が発生する。各球状粒子の表面に生じた 弾性力に対して, 内部からこれに反発する弾性力が存在

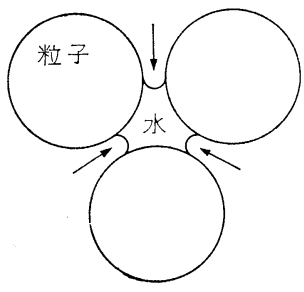

図-11間吵を水でへだ てられたラテックス 粒子
する。粒子間に存在する水は 缶の中では粒子を分離してお く役目をもっているが，塗装 されたラテックス中の水分が ある量（粒子を離して扔くの に必要な分散媒の濃度）以下 になると，蒸発の推進力とな る(図-11 参照)。水面は後退 して凹面になるので，毛細管 の壁面に張力が発生する。
この場合の毛細管とは六角状に密に充テンされた状態

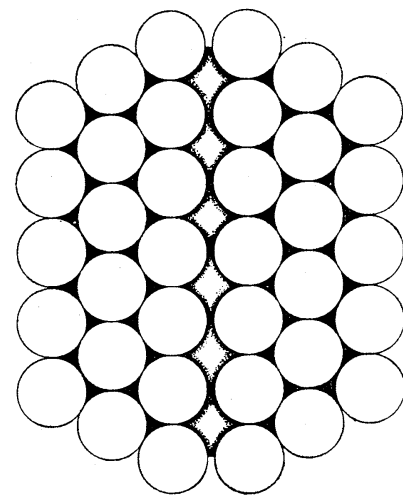

図-12 緊密充テンした粒子 にあるポリマー粒子 である。塗膜の長さ とか, 幅というよう な一つの巨視的な寸 法の中に断層線が存 在し，図-12 に見る ように密に充テンさ れた粒子が 10 個, 100 個，または 1000 個単位の大きさで存 在している。

この描写はやや思 索的過ぎるきらいがあったが, Krieger ${ }^{7)} ら は$ Paint

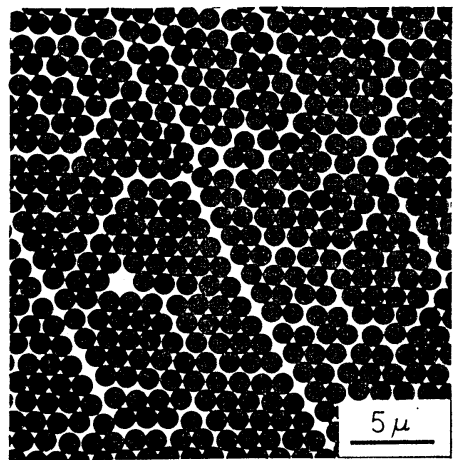

図-13 等径ラテックスに打ける断層線 (Wood による顕徽鏡写真) 
Research Institute の委託研究で図-13 に見るよらな， 実際に断層線で区切られた領域の存在することを顕微鏡 写真で証明した。この研究には，PRIの資金で開発され た Bobalek ら ${ }^{8)}$ の均一粒子径ラテックスと顕微鏡写真の 技術が使用されている。

\section{サイトの集団}

以上述べてきた諸現象は典型的な個体数増加現象に似 ている ${ }^{9)}$ 。すず第一に，シェアパルスの減衰 $\Delta$ の増加は MFT 以上（図-8，カーブ 4) で塗膜が乾燥するときに は図-5 のようにS字形をしているが，ホスト（ここで は素地のこと）が増加に耐えられなくなると，図-8，力 ーブ 1〜3のようにS字状の関係は急にとだえる。この 場合, $\log \Delta$ を時間に対してプロットすると直線部分が 得られ, 付着不良が起こるか否かによって, 特徵ある直 線部分の終り方をする。この直線関係は次の二つの期間 の間に存在する。すなわち，1) ほとんど個体数の増加の ない誘導期と，2)新らしい平たん部ができる飽和期とで ある。

次に図-8 の滑らかな曲線，あるいは図-9 の直線部分 を分析してみよう。図から見ると，乾燥曲線全体は図一 14 のよらに三つの部分から成っている。第一段階では 曲線は水平であり，この部分の性質は，後の段階を究明 するのに使われる測定法によっは明らかにされない。こ の曲線の最初の水平部分では集団は一つ一つ数えること ができる。(これは図の曲線上の点によって示される)し

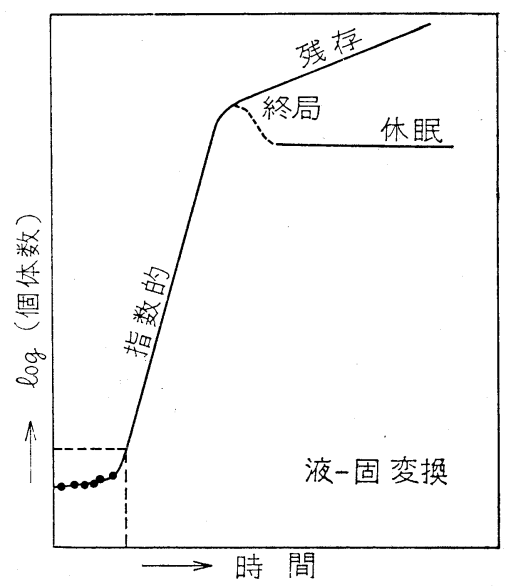

図-14 各時期に打ける典型的個体数増加曲線

かし，その後は統計的または推定值によってのみ測定さ れる。インピドメーターでは最初の平たん部の詳細を説 明することはできない。ただ，いつ誘導期が終り指数的 増加が始まるかは判別できる。インピドメーターは初期
段階における付着不良を検知し，塗膜がどのようにして 崩壊するかを示す手掛りとして生長相を観察するには有 益である。

ここでラテックスの乾燥に打いて遭遇する特殊条件を 考えてみよう。粒子間吵に存在する水の蒸発が起こらな いかぎり，図-11 に示すようなメニスカスは生じない。 実際, 粒子は等方性の環境にあり, 変形をらけない。こ れら粒子が点接触するときには, インピドメーター表面 の粒子群はその断面積から算出することができる。1 個

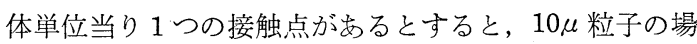
合, $1 \mathrm{~cm}^{2}$ 当りの個体密度は $10^{6}$ となる。この密度は分 散系濃度が臨界顔料容積濃度以下である限り $10^{6}$ 台であ る。

粒子間吵中の水の除去が始まるともはや個体を個々に

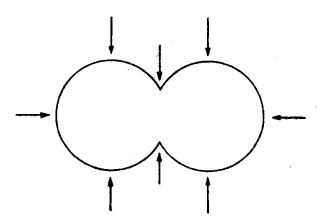

図-15 ラテックス粒子 の初期コアレッセンス 数えることができなくなり， まず最初に隣接した球状粒子 同志が図-15 に見るよらに変 形し，また素地に対しても平 らになってくる。点接触（面 積 0$)$ 加面接触 $\left(\mathrm{cm}^{2}\right.$ 単位 で測定され，全面積に対する 割合として表わされる) へと移行する。接触円が生長す るにつれてポリマーは素地からエネルギーを吸収して， シェアパルスの減衰が測定できるようになる。この生長 は素地との接触円が互いに接触するまで続き，この段階 で粒子の变形は新段階へ入り, 接触部は幾何学的には円 形から多角形になる。

この段階に入ると残存応力が塗膜の性質をきめる因子 となる。ガラスのように剛性率の高い粒子は，六方配列 を取るよらには十分な変形がでさない。MMA の含有率 の高いラテックスはガラス転移点 $\mathrm{T}_{\mathrm{g}}$ 以下の温度でなけ れば連続塗膜が形成できるほどじゆうぶんに変形するこ とができないが，EA の含有率の高いものは $\mathrm{T}_{\mathrm{g}}$ がじゆ らぶん低いので室温で六方形に变形が可能なので，連続 皮膜を形成することができる。

皮膜が崩壊するときのインピーダンスの急激な低下を 考劣ると, これは個体数の増加現象と完全に類似させる ことができる。ストレスといらものは人間集団のできご

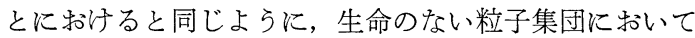
も同じような役目をする。ストレスは粒子の“社会”が 耐えられるかぎり生長する。しかし, その効果が感じら れるよらになると，まず最初の現われとして小社会への 分裂があり，これでストレスは解消されるが，それぞれ 分れた領域の大きなセグメントがプロセスの中で以前の 社会に取って代る。 
休止期は生長期ではないことに注意していただきた い。人口統計学の法規にしたがら諸現象では大きな異変 のあったあとでは成長の起きない期間がある。いつ, ど のようにして再び成長期が始まるかは, 始めの塗膜の乾 燥蔳する知識からはわからない。たと穴ば, もし, ポ リマーが永久的にカ橋されたものでなかったら，新しい 生長期の生長速度はキ裂の入った硬化塗膜の小片が素地 上でフローしょうとする傾向から見い出すことができ る。あるいは, もしシェアパルスの減衰の低下が可塑剤 その他の低分子量物質が塗膜と素地との境界面へ浸出し た結果であるとすると, 新しい成長期はこれら浸出物が 塗膜から蒸発するときに始まると考えることができる。

\section{結論}

アクリルテックスの乾燥性は典型的な個体数の増加現 象に似ている。素地上の個体密度が少なくて不連続であ る誘導期の次に個体数の指数的増加がある。後者では応 力が蓄積し, それは時には個体数の終末的な減少を起こ す。

セン断波を素地から鈅膜に伝ぱさせるといら超音波技 術は, 塗膜一素地界面での変化を検出する非破壊的な方 法である。これは減衰の簡単な測定によつて乾燥過程の 全段階にわたって集団の程度を反映するものである。

付着不良が発生すれば, その程度に比例して, 超音波 の減衰が起こる。
謝 辞

この研究は Corn Industries Research Foundation と Paint Research Institute の後援によって行なわれ た。また Research Corp. は二つのインペドメーターを, National Science Foundation の夏期プログラムからは 一つを提供された。H.J.McSimin は熱心な協力を与え られた。これらのことに対して深い感謝をささげる。

\section{文献}

1) Mason, W. P., Baker, W. O., McSimin, H. J. and Heiss, J. H., Phys. Rev. 731074 ; 1873 (1948) and 75946 (1946)

2) Barlow, A. J. and Lamb, J., Proc. Roy. Soc., 253A, No. 1272, 52 (1959)

3) Pellman, J.R. and Galt, J.K., J. Chem. Phys.. 14608 (1946)

4) McSkimin, H.J., J. Acoustical Soc. Am., 22 413 (1950)

5) Myers, R. R. and Schultz, R.K., Offic. Digest Federation Soc. Paint Technol., 34801 (1962)

6) Brown, G.L., J. Polymer Sci., 22423 (1956)

7) Woods, M. E., PhD Thesis, Case Western Reserve University, 1968 ; O'Neil, F. M., Thesis, Case Western Reserve University, 1967

8) Loranger, A.H., Serafini, T. T., von Fischer, W. and Bobalek, E. G., Offic. Digest Federation Soc. Paint Technol. 31482 (1959)

9) Price, D. J., Science Since Babylon, Yale Univ. Press, New Haven, Conn., 1961 